\title{
Mutants of Chinese Hamster Cells Deficient in Thymidylate Synthetase
}

\author{
I-CHIAN LI AND ERNEST H.Y. CHU* \\ Department of Human Genetics, Lawrence D. Buhl Center for Human Genetics, \\ University of Michigan Medical School, Ann Arbor, Michigan 48109
}

\begin{abstract}
Stable mutants of Chinese hamster V79 cells deficient in thymidylate synthetase (TS; E.C. 2.1.1.45) have been selected from cultures grown in medium supplemented with folinic acid, aminopterin, and thymidine (FAT). After chemical mutagenesis, the frequency of colonies resistant to the "FAT" medium increased more than 100-fold over the spontaneous frequency. The optimal expression time of the mutant phenotype was 5-7 days after mutagen treatment. The recovery of FAT-resistant colonies in the selective medium was not affected by the presence of wild-type cells at a density below 9,000 cells per $\mathrm{cm}^{2}$. All 21 mutants tested exhibited thymidine auxotrophy; neither folinic acid nor deoxyuridine could support mutant cell growth. There was no detectable TS activity in all 11 mutants so far examined and only about $50 \%$ of wild-type activity in three prototrophic revertants, as measured by whole-cell and cell-free enzyme assays. The apparent Michaelis-Menten constant $\left(K_{m}\right)$ for deoxyuridine-5'-monophosphate and inhibition constant $\left(K_{i}\right)$ for 5-fluorodeoxyuridine-5'-monophosphate, measured by whole-cell enzyme assay, appear to be similar for the wild-type and revertant cell lines. Using 5-fluoro-[6${ }^{3} \mathrm{H}$-2'-deoxyuridine $5^{\prime}$-monophosphate as active site titrant, the relative amounts of TS in crude cell extract from the parental, revertant, and mutant cells were shown to exist in a 1:0.5:0 ratio. Furthermore, the enzymes from two revertants were more heat labile than that of V79 cells. These properties, taken together, suggest that the FAT-resistant, thymidine auxotrophic phenotype may be the result of a structural gene mutation at the TS locus. The availability of such a mutant facilitates studies on thymidylate stress in relation to DNA metabolism, cell growth, and mutagenesis.
\end{abstract}

Thymidylate (dTMP) synthetase (TS, E.C. 2.1.1.45) is a pivotal enzyme in the biosynthesis of DNA, as it controls the only de novo source of thymidine 5 '-triphosphate (dTTP). The content of this enzyme in normal tissue is very low and in many cases undetectable, suggesting that it may be a rate-limiting enzyme in DNA synthesis (Blakley, 1960). However, the activity of TS is usually substantially elevated in proliferating cellular systems such as regenerating liver (Labow et al., 1969). Therefore, a block of the enzyme activity would exert dramatic effects upon tissues that require a high rate of DNA synthesis. Since many tumors fall into this category, TS becomes an attractive target enzyme for the design of cancer chemotherapy (Danenberg, 1977).

Mutants at the TS locus in phage, bacteria, and yeast have been particularly useful for the study of DNA metabolism in relation to cell growth and mutagenesis (Smith et al., 1973; Barclay and Little, 1978; Kunz and Haynes, 1982). Until recently this type of mutant had not been isolated from cultured mammalian somatic cells due, in part, to the lack of suitable selective systems. Ayusawa et al. $(1980,1981)$ were the first to isolate such mutants from the mouse mammary carcinoma FM $3 \mathrm{~A}$ cell line by the use of either a tritium suicide $\left({ }^{3} \mathrm{H}\right.$ - deoxyuridine) method or by virtue of the reduced sensitivity of mutants to methotrexate (MTX). However, the first method is an indirect procedure and the second selects primarily for mutants defective in dihydrofolate reductase (DHFR) (Albrecht et al., 1972; Flintoff et al., 1976).

Based on the MTX-leucovorin rescue regimen for cancer chemotherapy (Mehta et al., 1979; Sauer et al., 1979), we have formulated a new selective medium which contains folinic acid, aminopterin, and thymidine (the "FAT" medium). In this report, we describe (1) the formulation of the selective medium, (2) single-step direct selection of FAT-resistant (FAT ${ }^{\mathbf{r}}$ ) mutants, (3) the growth pattern, and (4) enzyme characteristics of the FAT ${ }^{\mathrm{r}}$ mutants and FAT-sensitive (FAT ${ }^{\text {s }}$ ) revertants. All mutant isolates exhibit thymidine (dThd) auxotrophy and a reduced or nondetectable TS activity. A brief summary of this work has appeared ( $\mathrm{Li}$ and $\mathrm{Chu}, 1982)$.

Received October 6, 1983; accepted February 27, 1984.

*To whom reprint requests/correspondence should be addressed. 


\section{MATERIALS AND METHODS Materials}

Aminopterin, folinic acid, 5-fluorodeoxyuridine (5FdUrd), dl-5,6,7,8 tetrahydrofolic acid $\left(\mathrm{FH}_{4}\right)$, and Tween 80 were purchased from Sigma Chem. Co., St. Louis, MO. $\quad\left[5^{3} \mathrm{H}\right]-2^{\prime}$-deoxyuridine 5 '-monophosphate $\left({ }^{3} \mathrm{H}\right.$ dUMP) $(12-14.8 \mathrm{Ci} / \mathrm{mmol}, 0.5-1.0 \mathrm{mCi} / \mathrm{ml})$ was purchased from either Schwarz/Mann Chem. Co. (Spring Valley, NY) or Amersham Co. (Arlington Heights, IL); 5-fluoro- $\left[6{ }^{3} \mathrm{H}\right]-2^{\prime}$-deoxyuridine $5^{\prime}$-monophosphate $\left({ }^{3} \mathrm{H}\right.$ FdUMP) (18 Ci/mmol, $1 \mathrm{mCi} / \mathrm{ml}$ ) was obtained from Moravek Biochemicals Inc., Brea, CA.

\section{Cell culture}

The Chinese hamster lung cell line, V79, was used in all experiments. Unless otherwise indicated, the cells were grown in Dulbecco's modified Eagle's minimum essential medium (D-10) supplemented with 5\% dialyzed fetal calf serum (DFCS), $1 \mathrm{mM}$ sodium pyruvate, 1.5 times the normal levels of vitamins and essential amino acids, and twice the concentrations of non-essential amino acids. The medium contains $2.27 \mu \mathrm{M}$ folic acid.

\section{Mutagen treatment and mutant selection}

Cells were seeded into 9-cm culture dishes at $1 \times 10^{6}$ cells per dish. Six hours later ethyl methanesulfonate (EMS) was added to a final concentration of $400 \mu \mathrm{g} / \mathrm{ml}$. After $18 \mathrm{hr}$, the cells were washed, grown, and subcultured as necessary in D-10 with FCS and $10 \mu \mathrm{m}$ dThd for 2-11 days to allow expression of the mutant phenotype.

For the selection of mutants, $5 \times 10^{5}$ cells were seeded into 9-cm dishes in D-10 supplemented with DFCS and appropriate concentrations (see below) of aminopterin, folinic acid and dThd. Surviving colonies were picked or counted after 10-14 days. The medium was renewed once during the selection period. The frequency of resistant colonies was measured after correcting for plating efficiency.

\section{Whole-cell TS assay}

The enzyme activity was assayed by measuring the release of tritiated water from $\left[5-{ }^{3} \mathrm{H}\right]$-dUMP according to the procedure of Lomax and Greenberg (1967).

The cell permeabilization method used was modified from that of Lewis et al. (1978). Samples of $1 \times 10^{7}$ cells were harvested from exponentially growing cultures in D-10 with 5\% FCS and $1 \mu \mathrm{M}$ dThd. After washing once with phosphate-buffered saline, the cells were suspended in $1 \mathrm{ml}$ permeabilizing buffer, which contained $100 \mathrm{mM}$ HEPES buffer, pH 7.6, $100 \mathrm{mM}$ mercaptoethanol, $250 \mathrm{mM}$ sucrose, and $1 \%$ Tween 80 . The cells were allowed to stand at room temperature for $30 \mathrm{~min}$, with occasional gentle shaking, and centrifuged at 15,000g for 6 sec. The cell pellet was then resuspended in cold permeabilizing buffer to a final concentration of $2 \times 10^{7}$ cells per ml. Fifty microliters of the cell suspension was mixed with $50 \mu \mathrm{l}$ of reaction mixture, which contained $2.66 \mathrm{mM} \mathrm{FH}_{4}, 9.6 \mathrm{mM}$ formaldehyde, $100 \mathrm{mM}$ mercaptoethanol, $10 \mathrm{mM}$ sodium bicarbonate, $60 \mathrm{mM}$ HEPES buffer, $\mathrm{pH} 7.6$, and $80 \mu \mathrm{M}\left[5-{ }^{3} \mathrm{H}\right]-\mathrm{dUMP}(13.9 \mathrm{mCi} / \mathrm{mmol})$. The concentrations of components and the $\mathrm{pH}$ of the buffer were optimized and the reaction was linear up to $1 \mathrm{hr}$. A control reaction included all components but was stopped at time zero. All assays were conducted in triplicate. After $30 \mathrm{~min}$ at $37^{\circ} \mathrm{C}, 2 \mathrm{ml} 15 \%$ Norit A charcoal in $4 \%$ perchloric acid was added to stop the enzyme reaction. The entire mixture was left at room temperature for $30 \mathrm{~min}$ with occasional vortexing. The mixture was filtered through a Whatman GF/A glass fiber filter disc. One hundred microliters of clear filtrate was mixed with $5 \mathrm{ml}$ of aqueous counting solution (Amersham Chem. Co., Arlington Heights, IL) and the radioactivity counted. TS activity is expressed as pmol dTMP formed per $10^{6}$ cells per $\mathrm{hr}$.

The Michaelis-Menten constant $\left(\mathrm{K}_{\mathrm{m}}\right)$ for dUMP and the inhibition constant $\left(\mathrm{K}_{\mathrm{i}}\right)$ for FdUMP were determined using the whole-cell TS assay. FdUMP was added to the reaction mixture reaching a final concentration in the range of $10^{-9} \mathrm{M}-10^{-8} \mathrm{M}$. $\mathrm{K}_{\mathrm{i}}$ values were estimated graphically by either a plot of $1 / V$ versus $i$ (the Dixon plot; Dixon, 1953) or a plot of $\mathrm{s} / \mathrm{v}$ versus $\mathrm{s}$ (the HanesWoolf plot; Dixon and Webb, 1964).

\section{TS assay in cell extract}

Exponentially growing cells were harvested, washed, and suspended at $2 \times 10^{7}$ cells $/ \mathrm{ml} 100 \mathrm{mM}$ HEPES buffer, pH 7.6, with $100 \mathrm{mM}$ mercaptoethanol. The cells were disrupted by sonication. The supernatant, obtained by centrifugation at $15,000 \mathrm{~g}$ for $10 \mathrm{~min}$, was used as a crude enzyme preparation. Fifty microliters of the cell extract was mixed with $50 \mu \mathrm{l}$ of reaction mixture which has been specified in the whole-cell assay. From then on the procedure of enzyme assay was identical to that for the whole-cell assay. TS activity is expressed as pmol dTMP formed per $\mu \mathrm{g}$ protein per hr. Protein was determined by the method of Bradford (1976) using bovine serum albumin as standard.

\section{Heat inactivation of TS}

The assay was essentially the same as above except that the cell extract was heated at $38^{\circ}, 40^{\circ}$, or $42^{\circ} \mathrm{C}$ for various times. The amount of protein in the reaction tubes were adjusted to the same level for each cell line.

\section{Determination of TS levels}

The amount of the TS enzyme in cytosol was determined by measuring the binding of ${ }^{3} \mathrm{H}$-FdUMP in the presence of $5,10-\mathrm{CH}_{2}-\mathrm{FH}_{4}$ according to the published procedures (Santi et al., 1974a; Lockshin et al., 1979). The number of FdUMP binding sites can be taken as a direct measure of the enzyme level in the cell.

Concentrated cell extract was prepared from $1 \times 10^{7}$ cells per $100 \mu \mathrm{l}$ buffer. The $100-\mu \mathrm{l}$ reaction mixture contained $100 \mathrm{mM}$ mercaptoethanol, $133 \mu \mathrm{M} \mathrm{FH}_{4}, 480 \mu \mathrm{M}$ formaldehyde, $100 \mathrm{mM}$ HEPES, $\mathrm{pH} 7.6,55 \mathrm{nM}$ (18 Ci/ mmol) ${ }^{3} \mathrm{H}-\mathrm{FdUMP}$, and various amounts of cell extract corresponding to cell numbers ranging from $2 \times 10^{5}$ to $2 \times 10^{6}$. The reaction was carried out at room temperature for $60 \mathrm{~min}$ and stopped by the addition of $4 \mathrm{ml} 10 \%$ tricholoroacetic acid with $2 \%$ sodium pyrophosphate. Under these conditions in the presence of excess amounts of ${ }^{3} \mathrm{H}-\mathrm{FdUMP}$ and $\mathrm{CH}_{2}-\mathrm{FH}_{4}$, the reaction was linear up to $150 \mu \mathrm{g}$ protein, which is equivalent to $2.5 \times 10^{6}$ cells. This result is similar to that obtained by Santi et al. (1974a). After standing at $4^{\circ} \mathrm{C}$ for $30 \mathrm{~min}$, the protein precipitate was collected on a Whatman GF/C fiber glass filter disc. The disc was dried under a heating lamp and the radioactivity counted in an organic counting solution (Amersham Chem. Co.). 


\section{RESULTS}

\section{Development of the selective medium}

The rationale for the selection of $\mathrm{FAT}^{\mathrm{r}}$ mutant is as follows: In mammalian cells, dTMP synthesis is inhibited by the folic acid antagonist aminopterin, which tightly binds to the enzyme dihydrofolate reductase (DHFR), preventing the conversion of dihydrofolate to $\mathrm{FH}_{4} . \mathrm{FH}_{4}$ functions as a recipient of one-carbon groups from various sources and is directly involved in purine and amino acid metabolism as well as dTMP biosynthesis (Fig. 1). When wild-type cells are grown in culture in the presence of aminopterin, dTMP synthesis rapidly depletes the intracellular supply of $\mathrm{FH}_{4}$, thereby inhib. iting cell growth. In contrast, the $\mathrm{FH}_{4}$ level is conserved in TS-deficient cells grown in medium containing aminopterin. Under these conditions, the viability and growth of the mutant cells can be maintained if the cells are also supplied with dThd and one of the interconversion metabolites of $\mathrm{FH}_{4}$.

To develop the selective medium V79 cells were grown in D-10 supplemented with 5\% DFCS and various concentrations of aminopterin. Aminopterin at $1 \mu \mathrm{M}$ reduced cell survival to less than $10^{-7}$. In the next experiment, TS activity in V79 cells was chemically inhibited with various concentrations of 5-fluorodeoxyuridine (FdUrd) and $10 \mu \mathrm{M}$ dThd for $16 \mathrm{hr}$. Without medium change, a mixture of $1 \mu \mathrm{M}$ aminopterin and various concentrations of folinic acid was added. The purpose of the experiment was to test the rescuing effect of folinic acid. The conserved intracellular $\mathrm{FH}_{4}$ pool could not by itself support cell growth when both TS and
DHFR were inhibited (Fig. 2A). Cell growth could, however, be restored to varying levels by the addition of folinic acid to the medium (Fig. 2A,B). To allow cells to proliferate normally in the presence of aminopterin and dThd, exogenous folinic acid should be present at least $0.1 \mu \mathrm{M}$ at a time when TS activity is assumed to be totally blocked by $10 \mu \mathrm{M}$ of FdUrd. A provisional selective medium was formulated: D-10 with 5\% DFCS, 10 $\mu \mathrm{M}$ dThd, $1 \mu \mathrm{M}$ aminopterin, and $0.1 \mu \mathrm{M}$ folinic acid. Subsequent to the isolation of TS-deficient mutants, the concentrations of folinic acid and dThd needed for normal growth of mutant cells were adjusted. Figure 2C shows that folinic acid at $0.1 \mu \mathrm{M}$ was able to support fully the growth of mutant cells, but not the wild-type cells, in D-10 containing DFCS, $1 \mu \mathrm{M}$ aminopterin, and $10 \mu \mathrm{M}$ dThd. The appropriate concentration of dThd in the FAT medium was determined as $1 \mu \mathrm{M}$ (Fig. 2D).

Glycine at concentrations ranging from 0 to $10^{-2} \mathrm{M}$ was added to a special FAT medium which contained no glycine (normal D-10 has $2 \times 10^{-4} \mathrm{M}$ glycine). A plating experiment of a FAT $^{\mathrm{r}}$ cell clone (TS-3A) revealed that additional supplement of glycine was not necessary (data not shown).

\section{Selection condition for FAT $^{\mathrm{r}}$ mutants}

FAT ${ }^{\mathrm{r}}$ cells occurred spontaneously in V79 cell populations at an average frequency of $1.1 \times 10^{-7}$. The frequency increased to an average of $0.9 \times 10^{-5}$ in populations treated with EMS at $400 \mu \mathrm{g} / \mathrm{ml}$. In a reconstruction experiment in which 200 FAT $^{r}$ cells were mixed with varying numbers of wild-type cells, the re-

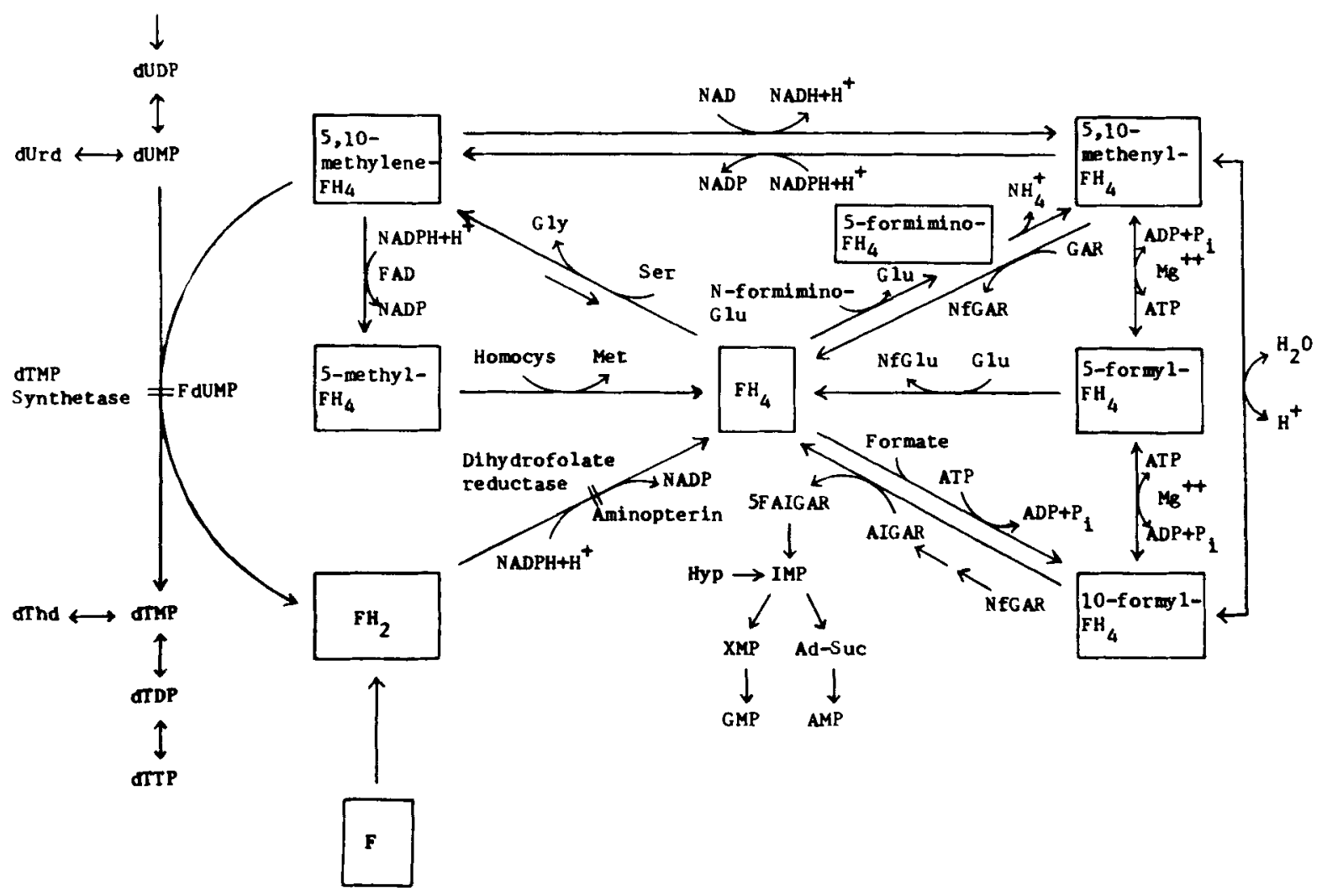

Fig. 1. Interconversion of tetrahydrofolate and its derivatives in mammalian cells. 

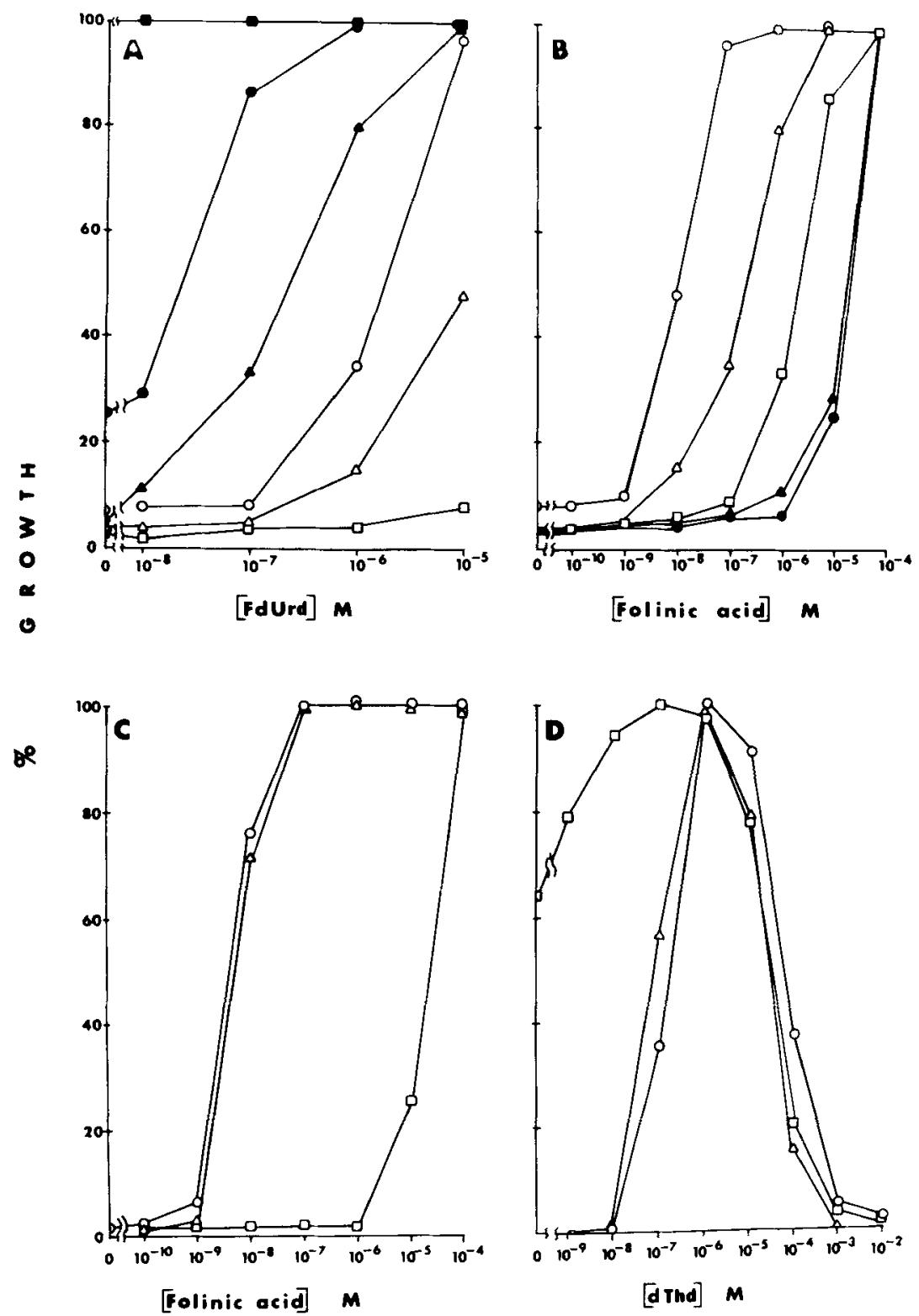

Fig. 2. Growth response of the parental, mutant, and revertant cell lines in various media. To measure cell growth, $1 \times 10^{3}$ cells were seeded into 6-cm culture dishes containing different media. Seven days later cells in each dish were lysed with $2 \mathrm{ml} 1 \mathrm{~N} \mathrm{NaOH}$, and absorbance at $260 \mathrm{~nm}$ was measured. The highest reading of absorbance from the dish with the largest amount of cells was taken as $100 \%$. A. The combined effects of 5-fluorodeoxyuridine (FdUrd) and folinic acid on the reversal of cytotoxicity of aminopterin on Chinese hamster V79 cells. The medium was D-10 containing 5\% dialyzed fetal calf serum, $10 \mu \mathrm{M}$ thymidine, $1 \mu \mathrm{M}$ aminopterin, and various concentrations of folinic acid and FdUrd. Folinic acid was present at (D) $0 \mathrm{M} ; 10^{-10} \mathrm{M}$

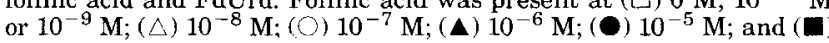

$10^{-4} \mathrm{M}$. B. The combined effects of folinic acid and FdUrd on the reversal of cytotoxicity of aminopterin on Chinese hamster V79 cells. Thymidine was present at $10 \mu \mathrm{M}$, aminopterin at $1 \mu \mathrm{M}$, folinic acid as indicated, and FdUrd at (๑) $0 \mathbf{M} ;(\Delta) 10^{-8} \mathbf{M} ;(\square) 10^{-7} \mathbf{M} ;(\triangle) 10^{-6}$ $\mathrm{M}$; and $(O) 10^{-5} \mathrm{M}$. C. Growth response of V79 $\left(\mathrm{FAT}^{\mathrm{s}}\right.$ ) and FAT ${ }^{\mathrm{r}}$ cells to different concentrations of folinic acid in D-10 medium containing $5 \%$ dialyzed fetal calf serum, $1 \mu \mathrm{M}$, aminopterin and $10 \mu \mathrm{M}$ thymidine. The cell lines used were (O) TS-4D; $(\triangle)$ TS-5A; and $(\square)$ V79. D. Growth response of the parental V79 $\left(\mathrm{FAT}^{\mathrm{S}}\right)$ and FAT ${ }^{\mathrm{r}}$ cells in the presence of different concentrations of thymidine in D-10 medium with $5 \%$ dialyzed fetal calf serum. The cell lines used were $(\sqcup)$ V79; $(\triangle)$ TS-4D; and $(O)$ TS- $8 \mathrm{~A}$.

covery of FAT ${ }^{r}$ colonies in FAT medium was not affected by the presence of as many as $5 \times 10^{5}$ wild-type cells per 9-cm culture dish $\left(\simeq 9,000\right.$ cells per $\left.\mathrm{cm}^{2}\right)$. At higher cell densities the recovery of FAT ${ }^{\mathrm{r}}$ cells was reduced.

The optimal time required for the expression of the mutant phenotype was examined by determining the frequency of FAT ${ }^{\mathrm{r}}$ colonies at various times after EMS

mutagenesis. A maximum recovery $(100 \%)$ was observed on days 5 and 7 after mutagen treatment, followed by a decline $(67 \%)$ on day 11.

The growth behavior of FAT ${ }^{\mathrm{r}}$ mutants

All 21 FAT $^{\mathrm{r}}$ clones tested, out of a total of 46 isolated, exhibited dThd auxotrophy; neither folinic acid nor 
deoxyuridine could support cell growth (Table 1). Thus, the mutant clones appeared to be deficient in TS but not in thymidine kinase activity.

The average generation time of FAT $^{\mathbf{r}}$ cells was 21.3 $\mathrm{hr}$, as compared to $18.2 \mathrm{hr}$ for the parental cells. Therefore, the decline in the recovery of FAT colonies on day 11 after chemical mutagen treatment may be due to a slower growth of FAT ${ }^{\mathrm{r}}$ cells as compared to the parental cells.

The resistant phenotype was stable in three isolates maintained in D-10 supplemented with $1 \mu \mathrm{M}$ dThd for 4 months (TS-3A and TS-4D) or more than a year (TS10A). No revertants were found when tested in D-10 not supplemented with dThd. However, revertants, either spontaneous or EMS induced, occurred in mutant clones TS-8A and TS-5A. The spontaneous and EMS-induced $(200 \mu \mathrm{g} / \mathrm{ml})$ reversion frequencies were $3.8 \times 10^{-7}$ and $8.0 \times 10^{-6}$, respectively, for line TS-8A. The growth characteristics of the two revertant lines resembled that of the wild-type cells (Table 1).

The activity and properties of dTMP synthetase in mutants, revertants, and wild-type cells

The results of TS enzyme assay for five mutant clones, two revertants, and the wild-type cells are presented in Table 2. All 11 mutant isolates so far tested had a reduced or nondetectable TS acitivity. The residual TS activity in clones TS-3A and TS-4D was apprarently inadequate for dTMP synthesis and cell growth. On the other hand, about $50 \%$ of wild-type TS activity detected in the two revertants led to dThd independence.

It has been known for some time that FdUMP is a potent inhibitor of TS (Cohen et al., 1958). In the presence of $\mathrm{N}^{5}, \mathrm{~N}^{10}$-methylene tetrahydrofolate $\left(\mathrm{CH}_{2} \mathrm{FH}_{4}\right)$, the inhibitor forms a covalent bond complex with the enzyme (Santi and McHenry, 1972). Since the dissociation constant of the complex is lower than practical concentrations of the enzyme (Santi et al., 1974b), binding is stoichiometric and the inhibitor is, in fact, an active site titrant (Santi et al., 1974a). Two binding sites for FdUMP are present for each molecule of TS (Danenberg and Lockshin, 1982). Figure 3 shows the linear regression relationships between the amount of ${ }^{3} \mathrm{H}$ FdUMP bound and the amount of cell extract used for the TS active site titration. There was no increase of the bound radioactivity when cell number was increased in line TS-8A, or in wild-type cell extracts heated at $100^{\circ} \mathrm{C}$

TABLE 1. Growth response of V79 wild-type (FAT ${ }^{\mathrm{s}}$, FAT ${ }^{\mathrm{r}}$, and revertant cells

\begin{tabular}{|c|c|c|c|c|c|}
\hline \multirow[b]{2}{*}{ Cell line } & \multicolumn{5}{|c|}{$\begin{array}{l}\text { Relative plating efficiency }(\%) \text { in D-10 supplemented } \\
\text { with DFCS and }\end{array}$} \\
\hline & None & FAT & $\begin{array}{c}\text { dThd } \\
(10 \mu \mathrm{M})\end{array}$ & $\begin{array}{c}\mathrm{dUrd} \\
(10 \mu \mathrm{M})\end{array}$ & $\begin{array}{l}\text { Folinic acid } \\
(1 \mu \mathrm{M})\end{array}$ \\
\hline $\begin{array}{l}\text { Wild-type } \\
\text { Mutant }\end{array}$ & 65,2 & 0 & 100 & 98.9 & 65 \\
\hline TS-3A & 0 & 90.6 & 100 & 0 & 0 \\
\hline TS-4D & 0 & 98 & 100 & 0 & 0 \\
\hline TS-5A & 0 & 100 & 100 & 0 & 0 \\
\hline TS-8A & 0 & 100 & 100 & 0 & 0 \\
\hline TS. $10 \mathrm{~A}$ & 0 & 100 & 100 & 0 & 0 \\
\hline Revertant ${ }^{1}$ & & & & & \\
\hline TS 8 AR-S & 57 & 0 & 100 & 91.7 & 69 \\
\hline TS 8 AR-E & 61 & 0 & 100 & 88 & 52 \\
\hline
\end{tabular}

'S, spontaneous; E, EMS.induced.
TABLE 2. Thymidylate synthetase (TS) activity in V79 wild-type $\left(\mathrm{FAT}^{\mathrm{s}}\right), \mathrm{FAT}^{\mathrm{T}}$, and revertant cells

\begin{tabular}{lcc}
\hline Cell line & $\begin{array}{c}\text { Whole cell TS activity } \\
\text { (pmol dTMP/10 }\end{array}$ & $\begin{array}{c}\text { Cell extract TS activity } \\
\text { (pmol dTMP/ } / \mathrm{hg} \text { protein/hr) }\end{array}$ \\
\hline $\begin{array}{c}\text { Wild-type } \\
\text { Mutant }\end{array}$ & $973 \pm 112(5)^{1}$ & $9.2 \pm 0.2(3)^{1}$ \\
TS-3A & $27.3(2)$ & - \\
TS-4D & $15.5(2)$ & - \\
TS-5A & $\mathrm{ND}(3)$ & $\mathrm{ND}(2)$ \\
TS-8A & $\mathrm{ND}(4)$ & $\mathrm{ND}(4)$ \\
TS-10A & $\mathrm{ND}(5)$ & $\mathrm{ND}(4)$ \\
Revertant & & \\
TS 8 AR-S & $353 \pm 30(3)$ & $6.7(2)$ \\
TS 8 AR-S & $400(2)$ & $6.6(2)$ \\
\hline
\end{tabular}

${ }^{1}$ Total activity \pm S.D. Number in the parenthesis denotes the number of assays; $973 \mathrm{pmol}$ corresponds to $85,000 \mathrm{cpm} ; 973 \mathrm{pmol} / 10^{6} \mathrm{cell} / \mathrm{s} / \mathrm{hr}$ is equivalent to 16.2 $\mathrm{pmol} / \mu \mathrm{g}$ protein $/ \mathrm{hr}$. Hence TS activity assayed by the whole-cell method is about $\mathrm{pmol} / \mu \mathrm{g}$ protein/hr. Hence TS activity assayed by the whole-cell method is about
$75 \%$ higher than that by the cell-extract method. ND, not detectable; -, not done.

done.
${ }^{2} \mathrm{~S}$, spontaneous; E, EMS-induced.

for $2 \mathrm{~min}$, suggesting that no binding sites were available. From the slopes of regression lines, the amount of titratable TS active sites are found to be $0.68 \mathrm{pmol}$ per $10^{7}$ wild-type cells, $0.32 \mathrm{pmol}$ per $10^{7} \mathrm{TS} 8 \mathrm{AR}-\mathrm{E}$ cells, and 0.37 pmol per $10^{7}$ TS $8 A R-S$ cells. The relative amounts of TS hence exist approximately in a 1:0.5:0 ratio in the parental, revertant, and mutant cells, which is in approximate agreement with the ratio of detectable TS activity present in those cell lines.

The kinetic properties of TS from the wild-type and revertant cells are summarized in Table 3 . The apparent $\mathrm{K}_{\mathrm{m}}$ and $\mathrm{K}_{\mathrm{i}}$ values are similar between different cell lines examined. TS from revertant cells was more heat labile than that from the parental cells, as demonstrated by their relative thermostabilities tested at $42^{\circ}, 40^{\circ}$, or $38^{\circ} \mathrm{C}$. Only the results of $38^{\circ} \mathrm{C}$ inhibition are shown (Table 3, Fig. 4).

\section{DISCUSSION}

We have devised a direct selection method for TSdeficient mutants of Chinese hamster V79 cells. The method takes advantge of the drug-induced phenocopies of TS and DHFR deficiencies, which can be compensated by appropriate concentrations of exogenous folinic acid and dThd. The selective medium is Dulbecco's modified Eagle's minimum essential medium supplemented with $5 \%$ dialyzed fetal calf serum, $0.1 \mu \mathrm{M}$ folinic acid, $1 \mu \mathrm{M}$ aminopterin, and $1 \mu \mathrm{M}$ thymidine, as determined by cell growth experiments (Fig. 2). Folinic acid (5-formyl- $\mathrm{FH}_{4}$, also known as leucovorin or citrovorum factor) is stable in solution and can serve as a ready source of reduced folate to replenish the $\mathrm{FH}_{4}$ pools depleted by either MTX or aminopterin (Nahas et al., 1972). Aminopterin is known to be more toxic than MTX to cultured mammalian cells (Eagle and Foley, 1956). Folinic acid is more important than the other two components in the FAT medium for the recovery of TS mutants with a total enzyme deficiency. The medium was for the V79 cell line only; whether the formulation can be used for selection of $\mathrm{TS}^{-}$mutants from other mammalian cell lines remains to be tested.

Ayusawa et al. (1981) isolated TS-deficient mutants from mouse mammary carcinoma FM $3 \mathrm{~A}$ cells by virtue of the reduced sensitivity of the mutants to MTX. The selective medium they used contains vitamin $\mathrm{B}_{12}, 5$ - 


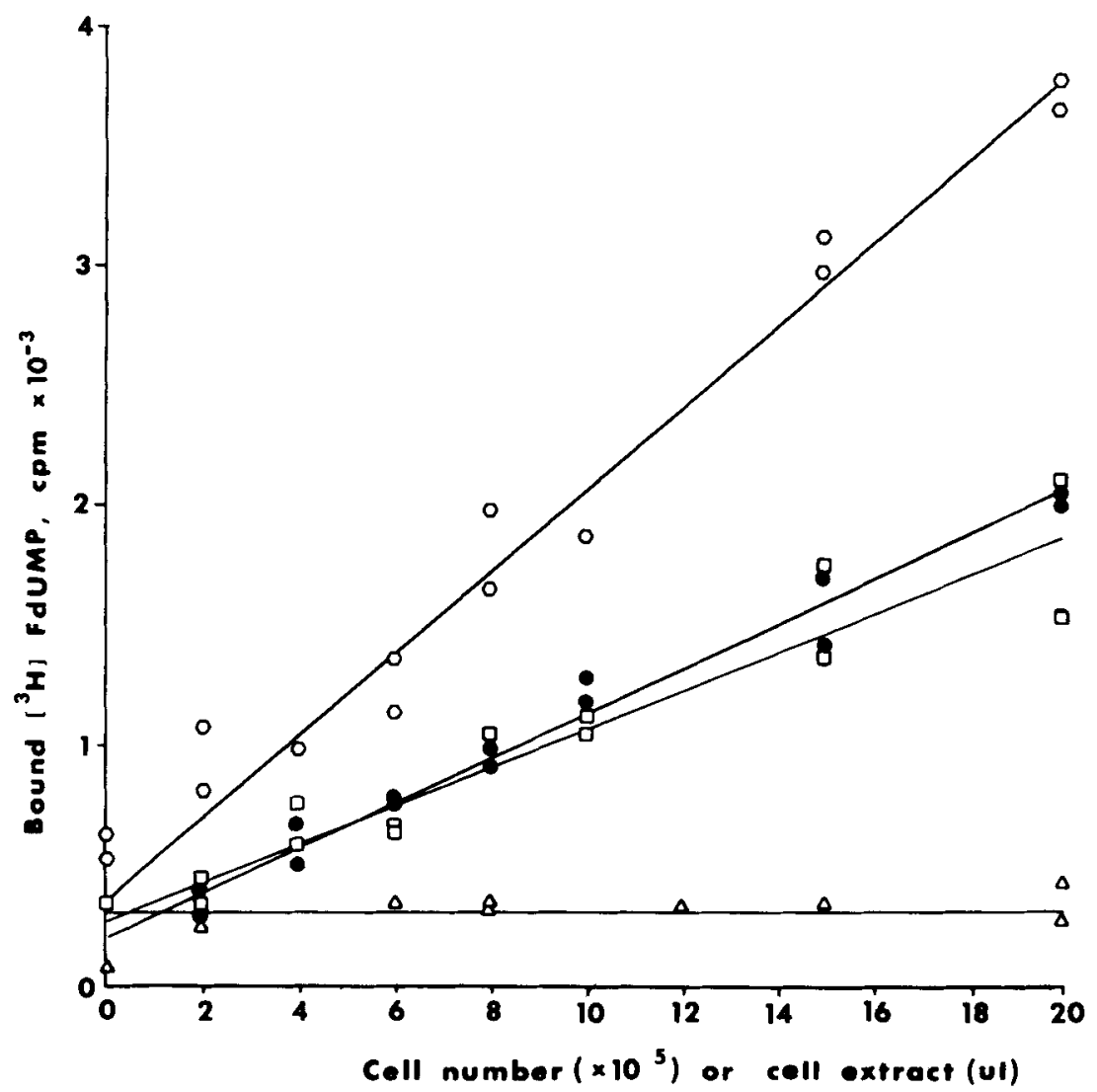

Fig. 3. The relationship between cell number and the amount of ${ }^{3} \mathrm{H}$ FdUMP bound in the FdUMP-TS- $\mathrm{CH}_{2}-\mathrm{FH}_{4}$ complex. Each regression curve was fitted by the pooled data of two independent experiments.

methyl- $\mathrm{FH}_{4}$, and folic acid. The inclusion of folic acid in the selective medium seems unnecessary, because its conversion to $\mathrm{FH}_{4}$ derivatives would be blocked by MTX. Moreover, 5-methyl- $\mathrm{FH}_{4}$ is a poor source of one-carbon groups for purine biosynthesis (Nixon et al., 1973). Exposure of V79 cells to this selective medium resulted in incomplete killing of cells, demonstrating the need for specific formulation of selective media for TS mutants in different cell types.

V79 cells are sensitive to FAT medium. The average spontaneous frequency of FAT ${ }^{r}$ colonies was $1.1 \times 10^{-7}$. The TS mutants we studied were sensitive to dThd-free medium, showing a spontaneous reversion frequency (to $\mathrm{FAT}^{\mathrm{S}}$ ) of $3.8 \times 10^{-7}$. A selection scheme is thus available for both forward and reverse mutations at the TS locus.

Complete deficiency in TS activity was observed in all 21 mutant isolates studied. The FAT-resistant, dThdauxotrophic phenotype was stable in three isolates (TS$3 \mathrm{~A}$, TS-4D, and TS-10A) but reversions occurred in the other two (TS-8A and TS-5A). Partial TS activity was restored in the revertant cells. Although the $\mathrm{K}_{\mathrm{m}}$ and $\mathrm{K}_{\mathrm{i}}$ values of the revertants studied did not differ appreciably from those of the wild-type V79 cells, the enzymes from two revertant cell lines of independent origin were more heat labile than the wild-type enzyme (Table 3, Fig. 4). The result supports the view that the altered phenotype was due to an altered enzyme, which probably is a result of a structural gene mutation at the TS locus.
The cell extracts used were ( $($ ) V79; (O) TS 8 AR-S; ( $\square)$ TS 8A R-E; and $(\triangle)$ V79 (heated) or TS-8A.

In mouse FM 3A cells, the TS locus is autosomal (Ayusawa et al., 1981). If this is true for the V79 Chinese hamster cells, then two alleles for the TS gene are expected to exist in the wild-type cells. Contradictory to this expectation, high frequencies of spontaneous and EMS-induced $\mathrm{TS}^{-}$mutants were observed. One explanation is that the TS locus is effectively hemizygous in the parental cells (Siminovitch, 1976; Gupta et al., 1978). If this is the case, the single functional TS allele might have mutated to give a low to nondetectable level of TS activity in the mutant cells. The TS levels in the cells as measured by active site titration reveal that no binding sites were available in mutant TS-8A and that the two revertants tested contained about half the amount of the enzyme as in the wild-type cells (Fig. 3). In the determination of apparent $K_{i}$ for FdUMP, the inhibition was

TABLE 3. Characteristics of thymidylate synthetase in V79 wild-type and revertant cells

\begin{tabular}{|c|c|c|c|c|}
\hline \multirow[b]{2}{*}{ Cell line } & \multirow{2}{*}{$\begin{array}{c}\mathrm{K}_{\mathrm{m}}(\mu \mathrm{M}) \\
\mathrm{s} / \mathrm{v} \text { vs. s plot }\end{array}$} & \multicolumn{2}{|c|}{$\mathrm{K}_{\mathrm{i}}(\mathrm{nM})$} & \multirow[b]{2}{*}{$\mathrm{T}_{1 / 2}{ }^{1}$} \\
\hline & & Dixon plot & s/v vs. s plot & \\
\hline Wild-type & $5.72 \pm 1.03(5)^{2}$ & $1.20(2)$ & $6.08(2)$ & $33 \quad(2)$ \\
\hline \multicolumn{5}{|l|}{ Revertant } \\
\hline TS 8 AR-S & $4.65 \pm 0.43(3)$ & $1.90(2)$ & $4.11(2)$ & $16 \quad(2)$ \\
\hline TS 8 AR-E & $5.96 \pm 1.36(5)$ & $1.15(2)$ & $4.06(2)$ & $14.5(2)$ \\
\hline TS 5 AR-E & $5.72(2)$ & - & -- & - \\
\hline
\end{tabular}

${ }^{1}$ Time in min at $38^{\circ} \mathrm{C}$ needed to inactivate $50 \%$ of TS activity.

${ }^{2} \pm$ S.D. No. in the parenthesis indicates the No. of assays. -, not done. 


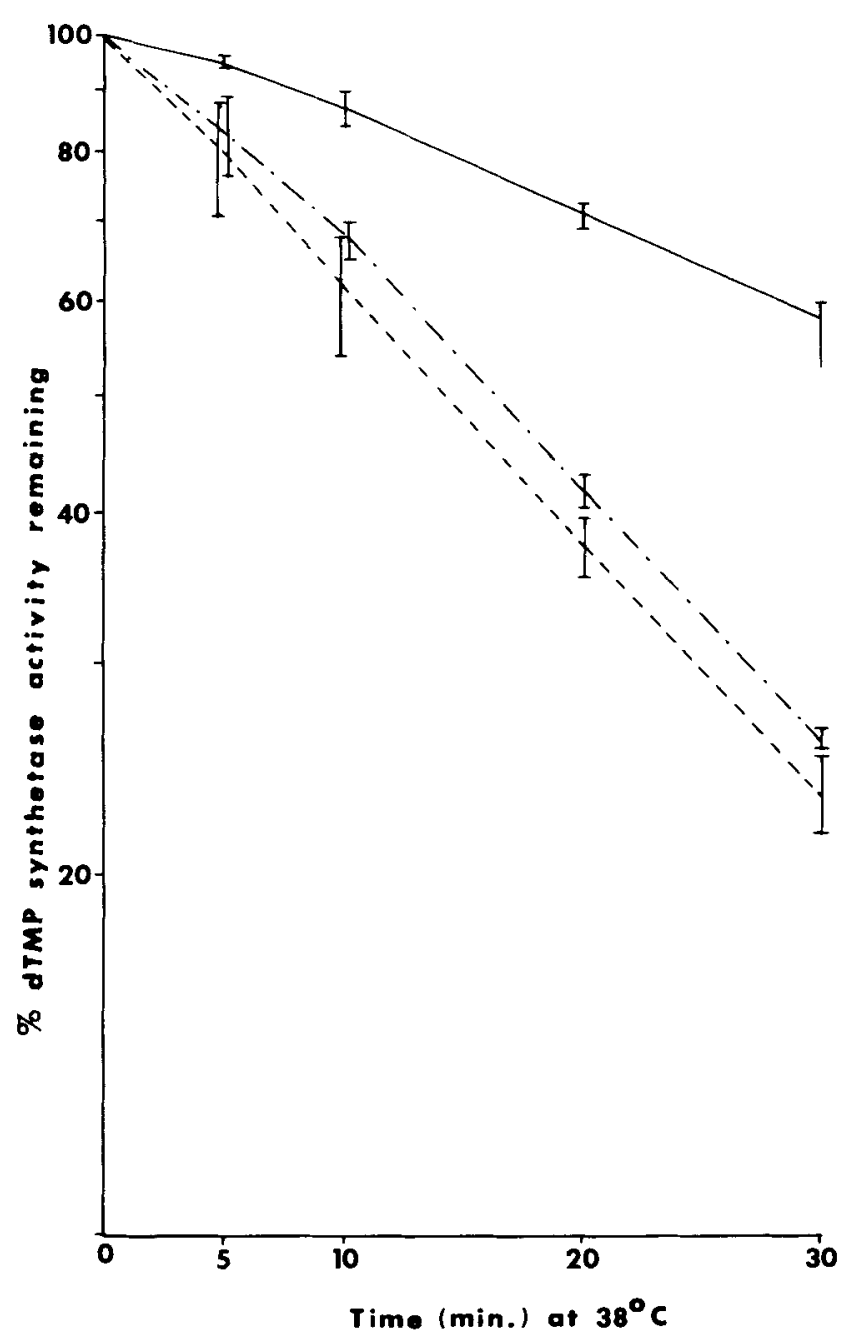

Fig. 4. Heat $\left(38^{\circ} \mathrm{C}\right)$ inactivation curve of TS activity from the parental (-_), the revertant TS $8 \mathrm{~A}$ R-S (-..), and the revertant TS 8A R-E (- - - cells.

assumed to be steady-state in nature although another reaction nature is also possible (Cha, 1975). Our data agree well with those obtained by Bissan and Thorner (1981), who also assumed a steady-state reaction for the FdUMP inhibition of the purified TS from the yeast. Since the apparent $K_{i}$ values for FdUMP of TS from the two revertants are approximately the same as that of the wild-type enzyme (Table 3 ), the revertants probably had a lowered number of enzyme molecules per cell rather than a lowered affinity of the enzyme for the dUMP analog. This differs from the 5-FdUMP-resistant human leukemic cells which contained a TS with a lower affinity for FdUMP (Bapat et al., 1983). Our measurement of TS levels by active site titration (Fig. 3) in the parental, mutant, and revertant cells are in good agreement with measurements of TS activities in the same cells. It is interesting to note that partial activity of the enzyme in two revertants appears to be sufficient to convert dThd auxotrophy to prototrophy.

Deficiency of TS has not been recognized in any metabolic disease in man. However, dThd deficiency has been suggested to be responsible for $\mathrm{X}$-linked mental retar- dation in association with the fragile $\mathrm{X}$ chromosome in man (Glover, 1980). It will be interesting to see if somatic cells from these patients have reduced levels of TS activity. The availability of TS $^{-}$mutants will facilitate the study of folate metabolism, as perturbed by the high level of a conserved $\mathrm{FH}_{4}$ pool.

The genetic effects of thymine nucleotide deprivation in eukaryotic cells have been well documented (see review: Kunz, 1982). The effects include increased incidence of mutagenesis, recombinagenesis, sensitivity to ultraviolet light, chromosome aberrations, and sister chromatid exchanges. However, none of these phenomena has been examined in mammalian mutant cells defective in TS. We have constructed double mutant cell lines of V79 cells defective at both the TS and cytidine 5 'triphosphate (CTP) synthetase loci (Chu et al., 1982). These double mutants with elevated CTP and dCTP pools and diminished dTTP pools would allow experimental manipulation of the cellular DNA precursors, in relation to the fidelity of DNA replication and mutagenesis in mammalian cells.

\section{ACKNOWLEDGMENTS}

This research was supported by U.S. Public Health Service grants GM20608 and CA 26803.

\section{LITERATURE CITED}

Albrecht, A.M., Biedler, J.L., Hutchison, D.J. (1972) Two different species of dihydrofolate reductase in mammalian cells differentially resistant to amethopterin and metasquin. Cancer Res., 32:15391546.

Ayusawa, D., Koyama, H., Iwata, K., and Seno, T. (1980) Single-step selection of mouse FM 3A cell mutants defective in thymidylate synthetase. Somat. Cell Genet., 6:261-270.

Ayusawa, D., Koyama, H., Iwata, K., and Seno, T. (1981) Selection of mammalian thymidylate auxotrophic cell mutants defective in thymidylate synthetase by their reduced sensitivity to methotrexate. Somat. Cell Genet., 7:523-534.

Bapat, A.R., Zarow, C., and Danenberg, P.V. (1983) Human leukemic cells resistant to 5-fluoro-2'-deoxyuridine contains a thymidylate synthetase with lower affinity for nucleotides. J. Biol. Chem., 258:4130-4136.

Barclay, B., and Little, J.G. (1978) Genetic damage during thymidylate starvation in Saccharomyces cerevisiae. Mol. Gen. Genet., 160:33-40.

Bissan, L.F., and Thorner, J. (1981) Thymidylate synthetase from Saccharomyces cerevisiae: Purification and enzymic properties. J. Biol. Chem., 256:12456-12462.

Blakley, R.L. (1960) The Biochemistry of Folic Acid and Related Pteridines. American Elsevier, New York, p. 217.

Bradford, M. (1976) A rapid and sensitive method for the quantitation of microgram quantities of protein utilizing the principle of proteindye binding. Anal. Biochem., 72:248-254.

Cha, S. (1975) Tight-binding inhibitors. I. Kinetic behavior. Biochem. Pharmacol., 24:2177-2185.

Chu, E.H.Y., MeLaren, J., Li, I.-C., and Lamb, B. (1982) Pleiotropic CTP synthetase mutants of Chinese hamster cells. Genetics, 100:s1213; Biochem. Genet. (in press).

Cohen, S.S., Flaks, J.G., Barner, H.D., Loeb, M.R., and Lichtenstein, J. (1958) The mode of action of 5-fluorouracil and its derivatives. Proc. Natl. Acad. Sci. USA, 44:1004-1012.

Danenberg, P.V. (1977) Thymidylate synthetase-a target enzyme in cancer chemotherapy. Biochim. Biophys. Acta, 473:72-92.

Danenberg, P.V. and Lockshin, A. (1982) Thymidylate synthetasesubstrate complex formation. Mol. Cell. Biochem., 43:49-57.

Dixon, M. (1953) The determination of enzyme inhibitor constants. Biochem. J., 55:170-171.

Dixon, M., and Webb, E.C. (1964) Enzymes. Academic Press, Inc., New York.

Eagle, H., and Foley, G. (1956) The cytotoxic action carcinolytic agents in tissue culture. Am. J. Med, 21:739-749.

Flintoff, W.E., Davidson, S.V., and Siminovitch L. (1976) Isolation and partial characterization of three methotrexate-resistant phenotypes from Chinese hamster ovary cells. Somat. Cell Genet., 2:245-261. 
Glover, T.W. (1981) FUdR induction of the X chromosome fragile site: Evidence for the mechanism of folic acid and thymidine inhibition. Am. J. Hum. Genet., 33:234-242.

Gupta, R.S., Chan, D.Y.H., and Siminovitch, L. (1978) Evidence for functional hemizygosity at the $\mathrm{Emt}^{\mathrm{R}}$ locus in CHO cells through segregation analysis. Cell, 14:1007-1013.

Kunz, B.A. (1982) Genetic effects of deoxyribonucleotide pool imbalances. Environ. Mutagen., 4:695-725.

Kunz, B.A. and Haynes, R.H. (1982) DNA repair and the genetic effects of thymidylate stress in yeast. Mutat. Res. 93:353-375.

Labow, R., Maley, G.F., and Maley, F. (1969) The effect of methotrexate on enzymes induced following partial hepatectomy. Cancer Res., $29: 366-372$.

Lewis, W., Kuzik, B.A., and Wright, J.A. (1978) Assay of ribonucleotide reduction in nucleotide-permeable hamster cells. J. Cell. Physiol. 94:287-298.

Li, I.C., and Chu, E.H.Y. (1982) Direct selection of mammalian cell mutants deficient in thymidylate synthetase. J. Cell Biol., 95:447a.

Lomax, M.I.S., and Greenberg, G.R. (1967) A new assay of thymidylate synthetase activity based on the release of tritium from deoxyuridylate- $5{ }^{3} \mathrm{H}$. J. Biol. Chem., 242:109-113.

Lockshin, A., Moran, R., and Danenberg, P. (1979) Thymidylate synthetase purified to homogeneity from human leukemic cells. Proc. Natl. Acad. Sci. USA, 76:750-754.

Mehta, B.M., Shapiro, W.R., Rosen, G., Hutchison, D.J. (1979) Distri bution of folates following methotrexate-leucovorin rescue regimen. in cancer patients. In: Chemistry and Biology of Pteridines. R. Kisliuk and G. Brown, eds. Elsevier North Holland, New York, pp. $677-$ 682.

Nahas, A., Nixon, P., and Bertino, J. (1972) Uptake and metabolism of $\mathrm{N}^{5}$-formyltetrahydrofolate by L1210 leukemia cells. Cancer Res. 32:1416-1421.

Nixon, P., Slutsky, G., Nahas, A., and Bertino, J. (1973) The turnover of folate coenzymes in murine lymphoma cells. J. Biol. Chem. 248:5932-5936.

Sauer, H., Schalhorn, A., and Williams, W. (1979) Biochemical control of the folinic acid rescue effect after high-dose methotrexate (MTX) therapy. In: Chemistry and Biology of Pteridines. R. Kisliuk and G. Brown, eds. Elsevier North Holland, New York, pp. 683-688.

Santi, D., and McHenry, C. (1972) 5-fluoro-2'-deoxyuridylate: Covalent complex with thymidylate synthetase. Proc. Natl. Acad. Sci. USA, 69:1855-1857.

Santi, D. McHenry, C., and Perriad, E.R. (1974a) A filter assay for thymidylate synthetase using 5 -fluoro-2'-deoxyuridylate as an active site titrant. Biochemistry, 13:467-470.

Santi, D., McHenry, C., and Sammer, H. (1974b) Mechanism of interaction of thymidylate synthetase with a 5-fluorodeoxyuridylate. Biochemistry, 13:471-480.

Siminovitch, L. (1976) On the nature of hereditable variation in cul tured somatic cells. Cell, 7:1-12.

Smith, M.D., Green, R.R., Ripley, L.S., and Drake, J.W. (1973) Thymineless mutagenesis in Bacteriophage T4. Genetics, 74:393-403. 